\title{
Canine and Bovine Neospora caninum Control Sera Examined for Cross-Reactivity Using Neospora caninum and Neospora hughesi Indirect Fluorescent Antibody
}

\section{Tests}

Author(s) :Luís F. P. Gondim, David S. Lindsay, Milton M. McAllister

Source: Journal of Parasitology, 95(1):86-88. 2009.

Published By: American Society of Parasitologists

DOI: http://dx.doi.org/10.1645/GE-1710.1

URL: http://www.bioone.org/doi/full/10.1645/GE-1710.1

BioOne (www.bioone.org) is a nonprofit, online aggregation of core research in the biological, ecological, and environmental sciences. BioOne provides a sustainable online platform for over 170 journals and books published by nonprofit societies, associations, museums, institutions, and presses.

Your use of this PDF, the BioOne Web site, and all posted and associated content indicates your acceptance of BioOne's Terms of Use, available at www.bioone.org/page/terms_of use.

Usage of BioOne content is strictly limited to personal, educational, and non-commercial use. Commercial inquiries or rights and permissions requests should be directed to the individual publisher as copyright holder. 


\title{
CANINE AND BOVINE NEOSPORA CANINUM CONTROL SERA EXAMINED FOR CROSS- REACTIVITY USING NEOSPORA CANINUM AND NEOSPORA HUGHESI INDIRECT FLUORESCENT ANTIBODY TESTS
}

\author{
Luís F. P. Gondim, David S. Lindsay*, and Milton M. McAllister† \\ Universidade Federal da Bahia, Escola de Medicina Veterinária, Departamento de Patologia e Clínicas, Av. Ademar de Barros 500, Ondina, \\ Salvador, Bahia, Brazil, 40170-110.e-mail: pita@ufba.br
}

\begin{abstract}
Neospora caninum is a well known protozoan parasite of domestic and wild animals. Neospora hughesi is a closely related protozoan with an unknown life cycle, host range, and infection prevalence. Many serologic surveys of $N$. caninum have been performed without consideration of potential cross-reactions with $N$. hughesi, which could confound results. The aim of this study was to investigate whether postexposure sera from animals experimentally infected with $N$. caninum exhibit significant reactivity differences when tested using $N$. caninum and $N$. hughesi Immunofluorescent Antibody Tests (IFAT). Pre- and postinfection serum samples from 10 dogs, 20 calves, and 17 cows were tested by dual IFATs. All pre-exposure samples for $N$. caninum tested seronegative for both organisms. All postexposure samples that were seropositive for $N$. caninum were also positive for $N$. hughesi, although $N$. hughesi antibody titers were usually 1 dilution lower $(P<0.02)$. Serologic surveys for $N$. caninum may be confounded by cross-reacting titers with $N$. hughesi, but true positive $N$. caninum antibody titers are greater than, or equal to, cross-reacting $N$. hughesi antibody titers.
\end{abstract}

Neospora caninum is a well-recognized protozoan parasite of domestic and wild animals (Anderson et al., 1991; Woods et al., 1994; Barber and Trees, 1996; Gondim, McAllister, MateusPinilla et al., 2004; Huang et al., 2004) that is frequently associated with bovine abortion worldwide (Dubey, 2003). It was classified in 1988 as the first species in the Neospora genus, based on structural and antigenic characteristics of asexual stages of the parasite (tachyzoites and encysted bradyzoites) observed in infected dogs (Dubey et al., 1988). Ten years after its classification, dogs were discovered to be definitive hosts of $N$. caninum (McAllister et al., 1998). Coyotes were also shown to be definitive hosts of the parasite (Gondim, McAllister, Pitt, and Zemlicka, 2004).

A similar organism isolated from a horse with myeloencephalitis (Marsh et al., 1996) was proposed as a new species, Neospora hughesi, based on molecular, antigenic, and structural differences when compared to N. caninum (Marsh et al., 1998). In other reports, major antigens of $N$. caninum and $N$. hughesi, i.e., SAG1, SRS2, GRA6, and GRA7, were compared and shown to be different (Marsh et al., 1999; Dubey et al., 2001; Walsh et al., 2001). Mice, horses, and a rabbit infected with $N$. hughesi have shown serologic reactivity with $N$. caninum (Marsh et al., 1998; Dubey et al., 2001; Packham et al., 2002; Hoane et al., 2005), and a rabbit infected with $N$. caninum had serologic reactivity with $N$. hughesi (Packham et al., 2002).

Serological studies for detection of animals with Neospora spp. have been reported by several authors (Cheadle et al., 1999; Vardeleon et al., 2001; Gupta et al., 2002; Packham et al., 2002; Dubey et al., 2003; Pitel et al., 2003). In these studies, it is not possible to know the actual number of $N$. hughesi- or $N$. caninum-infected animals. Recombinant ELISAs based on 29-kDa major surface antigens of $N$. caninum (rNc-SAG1) (Howe et al., 2002) and $N$. hughesi (rNh-SAG1) (Hoane et al., 2005) have been developed. These ELISAs exhibited high spec-

Received 22 May 2008; revised 26 June 2008; accepted 07 July 2008 * Center for Molecular Medicine and Infectious Diseases, Department of Biomedical Sciences and Pathobiology, Virginia-Maryland Regional College of Veterinary Medicine, Virginia Tech, Blacksburg, Virginia 24061-0342.

† Department of Veterinary Pathobiology, University of Illinois, 2001 South Lincoln Avenue, Urbana, Illinois 61802. ificities and sensitivities; however, cross-reactivity between $N$. caninum and $N$. hughesi was still observed (Hoane et al., 2005).

The aim of the present study was to investigate whether domestic animal hosts (dogs, calves, and cows) experimentally infected with $N$. caninum exhibit significant reactivity differences when tested using $N$. hughesi or $N$. caninum Immunofluorescent Antibody Tests (IFAT).

\section{MATERIALS AND METHODS}

\section{Animal sera}

Serum samples were obtained from calves, cows, and dogs that had been experimentally infected with $N$. caninum between 2000 and 2004 at the College of Veterinary Medicine at the University of Illinois at Urbana-Champaign, Illinois. Forty serum samples, including 20 preinfection and 20 postinfection sera, were obtained from newborn calves, which were intravenously infected with cultured tachyzoites or orally inoculated with sporulated oocysts of $N$. caninum (Gondim et al., 2002; Gondim, McAllister, Pitt, and Zemlicka, 2004). Twenty serum samples from dogs (10 pre-infection and 10 postinfection sera) were collected from dogs that consumed $N$. caninum-infected tissues (Gondim et al., 2002, 2005). Thirty-four cow sera, consisting of 17 pre-infection sera and 17 postinfection sera, were obtained from cows that were orally infected with $N$. caninum oocysts (Gondim, McAllister, AndersonSprecher et al., 2004).

\section{Parasites}

Tachyzoites of $N$. caninum (NC-beef strain) (McAllister et al., 2000) and $N$. hughesi (Nh-A1 strain) (Walsh et al., 2001) were cultured in Vero cells with RPMI containing L-glutamine, supplemented with $5 \%$ horse serum, $100 \mathrm{U} / \mathrm{ml}$ penicillin, and $100 \mu \mathrm{g} / \mathrm{ml}$ streptomycin. Tachyzoites were harvested when approximately $80 \%$ of the cell monolayers were infected. The infected cell suspensions were forced through 26gauge syringe needles, suspended in phosphate buffered saline, and filtered using $5-\mu \mathrm{m}$ syringe filters. The filtrate was washed 3 times by centrifugation $(1,200 \mathrm{~g}$ for $10 \mathrm{~min})$ in PBS, and the sediment was suspended in PBS to a final concentration of 500 to 1,000 tachyzoites/ $\mu l$. The purified tachyzoites were distributed on the wells of Teflon-coated glass slides, dried at room temperature, and fixed for $5 \mathrm{~min}$ in methanol. Antigen slides were stored at $-20 \mathrm{C}$ until further used.

\section{Immunofluorescent Antibody Test}

Serum samples were tested simultaneously for $N$. caninum and $N$. hughesi using antigen slides that were stored at $-20 \mathrm{C}$ for 1 to $5 \mathrm{wk}$. Dog and calf sera were screened at 1:50, and cow sera were screened at 1:200. Maximum antibody titers for both parasites were determined for all positive samples using doubling dilutions. Fluorescein-labeled 
TABLE I. Cross-reactivity of sera from Neospora caninum-infected animals with $N$. hughesi tachyzoites, as determined by Immunofluorescent Antibody Tests.

\begin{tabular}{|c|c|c|c|c|c|c|}
\hline & \multicolumn{6}{|c|}{ Animal sera } \\
\hline & \multicolumn{3}{|c|}{ Pre-infection with $N$. caninum } & \multicolumn{3}{|c|}{ Postinfection with $N$. caninum } \\
\hline & Dog & Calf & Cow & Dog & Calf & Cow \\
\hline Number of animals & 10 & 20 & 17 & 10 & 20 & 17 \\
\hline Number seropositive for $N$. caninum & 0 & 0 & 0 & 10 & 20 & 17 \\
\hline Number seropositive for $N$. hughesi & 0 & 0 & 0 & 10 & 20 & 17 \\
\hline Number with higher $N$. hughesi than $N$. caninum titer & - & - & - & 0 & 0 & 0 \\
\hline
\end{tabular}

$* P<0.02$

antiserum to bovine IgG and to dog IgG (Bethyl, Montgomery, Texas) was used as a conjugate for bovine and dog sera, respectively.

\section{Statistics}

The Wilcoxin Sign Test was used to compare $N$. caninum and $N$. hughesi serologic titers of dogs, calves, and cows.

\section{RESULTS}

In total, 94 serum samples from dogs, calves, and cows were used in the study, including 47 pre-exposure samples and 47 samples collected after exposure to $N$. caninum (tachyzoites, bradyzoites, or oocysts). The 47 pre-exposure samples for $N$. caninum, including 10 dog sera, 20 calf sera, and 17 cow sera, all tested seronegative for both $N$. caninum and $N$. hughesi. All $N$. caninum-infected animals tested seropositive by IFAT using $N$. hughesi tachyzoites; however, $N$. caninum antibody titers were significantly higher $(P<0.02$; usually 1 dilution difference) than were $N$. hughesi titers for dogs, calves, and cows (Table I). The IFAT titers for calves, cows, and dogs tested with $N$. caninum tachyzoites had ranges of 100-25,600, 400-6,400, and 100-1,600, respectively, while the IFAT titers tested with $N$. hughesi tachyzoites had ranges of 50-12,800, 200-3,200, and 50-800 for calves, cows, and dogs, respectively (Table II).

TABLE II. Antibody titers of calves, cows and dogs experimentally infected with Neospora caninum and tested by Immunofluorescent Antibody Tests (IFAT) using $N$. caninum and $N$. hughesi tachyzoites as antigens.

\begin{tabular}{|c|c|c|c|c|c|c|}
\hline \multicolumn{7}{|c|}{ Immunofluorescent antibody tests } \\
\hline \multirow{2}{*}{$\begin{array}{l}\text { Antibody } \\
\text { titers }\end{array}$} & \multicolumn{3}{|c|}{ For $N$. caninum } & \multicolumn{3}{|c|}{ For $N$. hughesi } \\
\hline & Calves & Cows & Dogs & Calves & Cows & Dogs \\
\hline 50 & 0 & $*$ & 0 & 1 & $*$ & 1 \\
\hline 100 & 1 & $*$ & 1 & 1 & $*$ & 1 \\
\hline 200 & 0 & 0 & 2 & 2 & 3 & 4 \\
\hline 400 & 3 & 5 & 1 & 2 & 5 & 0 \\
\hline 800 & 2 & 4 & 3 & 2 & 5 & 4 \\
\hline 1,600 & 2 & 4 & 3 & 2 & 1 & 0 \\
\hline 3,200 & 3 & 3 & 0 & 5 & 3 & 0 \\
\hline 6,400 & 5 & 1 & 0 & 4 & 0 & 0 \\
\hline 12,800 & 2 & 0 & 0 & 1 & 0 & 0 \\
\hline 25,600 & 2 & 0 & 0 & 0 & 0 & 0 \\
\hline
\end{tabular}

* Not tested at the referred serum dilution.

\section{DISCUSSION}

The present study highlights the potential for cross-reaction between $N$. caninum and $N$. hughesi serologic tests, which complicates the interpretation and confidence in the results of serological surveys for only 1 organism. To the our knowledge, this is the first time that sera from dogs and cattle experimentally infected with $N$. caninum have been tested using both $N$. caninum and $N$. hughesi tachyzoites as antigens. Serology for another closely related organism, Hammondia heydorni, was not included in the experiment because there is no test available to detect antibodies against this parasite.

The present study also shows that $N$. caninum postexposure sera from dogs and cattle that were tested in parallel by IFAT using $N$. caninum and $N$. hughesi tachyzoites exhibited higher titers when $N$. caninum was employed as antigen. Although $N$. caninum titers were higher than $N$. hughesi titers in $N$. canin$u m$-infected animals $(P<0.02)$, at the same time there was significant cross-reactivity with $N$. hughesi $(P<0.001)$. Therefore, serological surveys for $N$. hughesi may be confounded by titers to $N$. caninum. Although we were not able to compare the opposite effect $(N$. caninum titers in $N$. hughesi-infected animals), it seems probable that there is the same possibility for cross-reacting titers and false-positive results with $N$. caninum serology.

Packham et al. (2002) compared different serologic techniques (IFAT, ELISA, and DAT) using sera from horses experimentally infected with $N$. hughesi and concluded that IFAT was the only test, among the studied ones, that allowed discrimination between infected and noninfected horses. Recently, an ELISA test using a recombinant $N$. hughesi SAG1 antigen has been developed to detect $N$. hughesi antibodies in horses (Hoane et al., 2005); this test was shown to be more specific than the previous ones. However, it failed to discriminate between $N$. caninum- and $N$. hughesi-infected animals.

Natural infection with $N$. hughesi has not been reported in animals other than horses. This fact does not exclude the possibility that $N$. hughesi infects different domestic and wild animals. It is also expected that the definitive host of $N$. hughesi, which is unknown so far, is some widely distributed carnivore. It is reasonable to wonder if numerous serologic investigations of $N$. caninum-infected animals might have been confounded due to cross-reactions with $N$. hughesi. Another potentially confounding factor is infection with the closely related parasite Hammondia heydorni (Ellis et al., 1999), because there is no 
serologic technique available for detection of $H$. heydorni-infected animals. Therefore, at this moment, it is not possible to serologically differentiate $N$. hughesi, $N$. caninum, and H. heydorni infections. Certain differentiation of the 3 parasites is only possible when parasite DNA is obtained (Marsh et al., 1998; Ellis et al., 1999; Slapeta et al., 2002). Further studies are needed to develop specific serologic techniques for $N$. hughesi, $N$. caninum, and H. heydorni.

\section{ACKNOWLEDGMENTS}

The present work was supported by a USDA Hatch grant administered by the University of Illinois (ILLU-70-0341). Luís F. P. Gondim was recipient of a fellowship from Conselho Nacional de Desenvolvimento Científico e Tecnológico (CNPq), Brazil.

\section{LITERATURE CITED}

Anderson, M. L., P. C. Blanchard, B. C. Barr, J. P. Dubey, R. L. Hoffman, AND P. A. ConRAD. 1991. Neospora-like protozoan infection as a major cause of abortion in California dairy cattle. Journal of the American Veterinary Medical Association 198: 241-244.

Barber, J. S., AND A. J. Trees. 1996. Clinical aspects of 27 cases of neosporosis in dogs. Veterinary Record 139: 439-443.

Cheadle, M. A., D. S. Lindsay, S. Rowe, C. C. Dykstra, M. A. Williams, J. A. Spencer, M. A. ToIVIo-Kinnucan, S. D. Lenz, J. C. Newton, M. D. Rolsma, and B. L. Blagburn. 1999. Prevalence of antibodies to Neospora sp. in horses from Alabama and characterisation of an isolate recovered from a naturally infected horse [corrected]. International Journal for Parasitology 29: 1537-1543.

Dubey, J. P. 2003. Review of Neospora caninum and neosporosis in animals. Korean Journal of Parasitology 41: 1-16.

, J. L. Carpenter, C. A. Speer, M. J. Topper, and A. Uggla. 1988. Newly recognized fatal protozoan disease of dogs. Journal of the American Veterinary Medical Association 192: 1269-1285. , S. Liddell, D. Mattson, C. A. Speer, D. K. Howe, and M. C. Jenkins. 2001. Characterization of the Oregon isolate of Neospora hughesi from a horse. Journal of Parasitology 87: 345-353.

, S. M. Mitchell, J. K. Morrow, J. C. Rhyan, L. M. Stewart, D. E. Granstrom, S. Romand, P. Thulliez, W. J. Saville, and D. S. LINDSAY. 2003. Prevalence of antibodies to Neospora caninum, Sarcocystis neurona, and Toxoplasma gondii in wild horses from central Wyoming. Journal of Parasitology 89: 716-720.

Ellis, J. T., D. A. Morrison, S. Liddell, M. C. Jenkins, O. B. Mohammed, C. Ryce, And J. P. Dubey. 1999. The genus Hammondia is paraphyletic. Parasitology 118: 357-362.

Gondim, L. F. P., L. GaO, AND M. M. McAllister. 2002. Improved production of Neospora caninum oocysts, cyclical oral transmission between dogs and cattle, and in vitro isolation from oocysts. Journal of Parasitology 88: 1159-1163.

, M. M. McAllister, AND L. GAO. 2005. Effects of host maturity and prior exposure history on the production of Neospora caninum oocysts by dogs. Veterinary Parasitology 134: 33-39.

- - R. C. Anderson-Sprecher, C. BJorkman, T. F. Lock, L. D. Firkins, L. GAO, AND W. R. Fischer. 2004. Transplacental transmission and abortion in cows administered Neospora caninum oocysts. Journal of Parasitology 90: 1394-1400.

, N. E. Mateus-Pinilla, W. C. Pitt, L. D. Mech, and M. E. Nelson. 2004. Transmission of Neospora caninum between wild and domestic animals. Journal of Parasitology 90: 1361-1365.

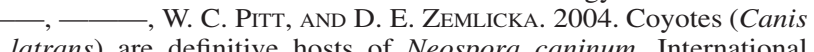
Journal for Parasitology 34: 159-161.
Gupta, G. D., J. Lakritz, J. H. Kim, D. Y. Kim, J. K. Kim, and A. E. MARSH. 2002. Seroprevalence of Neospora, Toxoplasma gondii and Sarcocystis neurona antibodies in horses from Jeju Island, South Korea. Veterinary Parasitology 106: 193-201.

Hoane, J. S., M. R. Yeargan, S. Stamper, W. J. Saville, J. K. MorROW, D. S. LindsAY, AND D. K. HowE. 2005. Recombinant NhSAG1 ELISA: A sensitive and specific assay for detecting antibodies against Neospora hughesi in equine serum. Journal of Parasitology 91: 446-452.

Howe, D. K., K. Tang, P. A. Conrad, K. Sverlow, J. P. Dubey, and L. D. Sibley. 2002. Sensitive and specific identification of Neospora caninum infection of cattle based on detection of serum antibodies to recombinant Ncp29. Clinical and Diagnostic Laboratory Immunology 9: 611-615.

Huang, C. C., C. H. Yang, Y. Watanabe, Y. K. Liao, and H. K. Ooi. 2004. Finding of Neospora caninum in the wild brown rat (Rattus norvegicus). Veterinary Research 35: 283-290.

Marsh, A. E., B. C. Barr, J. Madigan, J. Lakritz, R. Nordhausen, AND P. A. ConRAD. 1996. Neosporosis as a cause of equine protozoal myeloencephalitis. Journal of the American Veterinary Medical Association 209: 1907-1913.

A. E. Packham, And P. A. Conrad. 1998. Description of a new Neospora species (Protozoa: Apicomplexa: Sarcocystidae). Journal of Parasitology 84: 983-991.

, D. K. Howe, G. Wang, B. C. BARr, N. CAnnon, And P. A. ConRAD. 1999. Differentiation of Neospora hughesi from Neospora caninum based on their immunodominant surface antigen, SAG1 and SRS2. International Journal for Parasitology 29: 1575-1582.

McAllister, M. M., C. Bjorkman, R. Anderson-Sprecher, And D. G. Rogers. 2000. Evidence of point-source exposure to Neospora caninum and protective immunity in a herd of beef cows. Journal of the American Veterinary Medical Association 217: 881-887.

, J. P. Dubey, D. S. Lindsay, W. R. Jolley, R. A. Wills, And A. M. McGuIRE. 1998. Dogs are definitive hosts of Neospora caninum. International Journal for Parasitology 28: 1473-1478.

Packham, A. E., P. A. Conrad, W. D. Wilson, L. V. Jeanes, K. W. Sverlow, I. A. Gardner, B. M. Daft, A. E. Marsh, B. L. BlagBURn, G. L. FERraro, AND B. C. BARr. 2002. Qualitative evaluation of selective tests for detection of Neospora hughesi antibodies in serum and cerebrospinal fluid of experimentally infected horses. Journal of Parasitology 88: 1239-1246.

Pitel, P. H., S. Romand, S. Pronost, N. Foucher, G. Gargala, K. Maillard, P. Thulliez, C. Collobert-Laugier, D. Tainturier, G. Fortier, AND J. J. BALlet. 2003. Investigation of Neospora sp. antibodies in aborted mares from Normandy, France. Veterinary Parasitology 118: 1-6.

Slapeta, J. R., B. Koudela, J. Votypka, D. Modry, R. Horejs, And J. LUKES. 2002. Coprodiagnosis of Hammondia heydorni in dogs by PCR based amplification of ITS 1 rRNA: Differentiation from morphologically indistinguishable oocysts of Neospora caninum. Veterinary Journal 163: 147-154.

Vardeleon, D., A. E. Marsh, J. G. Thorne, W. Loch, R. Young, And P. J. Johnson. 2001. Prevalence of Neospora hughesi and Sarcocystis neurona antibodies in horses from various geographical locations. Veterinary Parasitology 95: 273-282.

Walsh, C. P., R. Vemulapalli, N. SRiranganathan, A. M. Zajac, M. C. JenKInS, AND D. S. LindSAY. 2001. Molecular comparison of the dense granule proteins GRA6 and GRA7 of Neospora hughesi and Neospora caninum. International Journal for Parasitology 31: 253258.

Woods, L. W., M. L. Anderson, P. K. Swift, and K. W. Sverlow. 1994. Systemic neosporosis in a California black-tailed deer (Odocoileus hemionus columbianus). Journal of the Veterinary Diagnostic Investigation 6: 508-510. 